\title{
中小河川流域における地上雨量データと高解像 度レーダデータを用いた面積雨量の比較検討
}

STUDY ON AREAL RAINFALL USING RAIN-GAUGE DATA AND HIGHRESOLUTION RADAR DATA IN MEDIUM AND SMALL RIVER BASINS

\author{
林義晃 1 手計太一2 2 山㟝惟義 3 \\ Yoshiaki HAYASHI, Taichi TEBAKARI and Koreyoshi YAMASAKI \\ 1正会員 学士 福岡大学教育技術職員 工学部社会デザイン工学科 \\ （广814-0180 福岡市城南区七隈8-19-1） \\ 2正会員 博 (工) 富山県立大学大学院准教授 工学研究科環境工学専攻 \\ （厂939-0398 富山県射水市黒河5180） \\ 3フェロー会員 工博 福岡大学教授 工学部社会デザイン工学科 \\ （干814-0180 福岡市城南区七隈8-19-1）
}

\begin{abstract}
The purpose of this study is to clarify the comparative study of areal rainfall of rain-gauge data and high-resolution radar data in medium and small river basins. This analysis used QPE of C-band radar and $\mathrm{X}$-band MP radar as areal rainfall of radar data. As estimated of areal rainfall of rain-gauge data, this study has divided numbers of each watershed by Thiessen method.

As a result of several analyses, areal rainfall of each radar data was similar to that of rain-gauge data. Areal rainfall of radar data haven't depended on domination area of a rain-gauge station. Areal rainfall of X-MP data wasn't difference from that of rain-gauge data in less than average altitude $300 \mathrm{~m}$ of sub river basin.
\end{abstract}

Key Words : areal rainfall, C-band radar, X-band MP radar, Kakehashi River, Tedori River.

\section{1. はじめに}

河川計画や洪水予報において，流域内の雨量分布や流 出特性を把握しておくことは非常に重要である。しかし， 実際の雨量分布の再現や，流出解析における地形や地質 など様々な条件の同定が複雑であるため，流出特性を正 確かつ詳細に把握することは困難な場合が多い1).

レーダによる雨量観測がはじまる以前において，雨量 データは地上雨量観測所による地点データしか存在しな かった。そのため, 流出解析に必要な面的な雨量分布は, ティーセン法や等雨量線法などを用いて流域平均雨量 (面積雨量)を算出していた。 その後，Cバンドレーダ (以下，レーダ雨量計)による面的な雨量分布を推定でき るようになり, 近年では高解像度かつ高頻度で雨量推定 ができるXバンドMPレーダ(同，X-MP)の雨量観測が開 始され，より精密な雨量分布の把握が期待される.

そのため，これまでに面積雨量に関する多くの研究が 実施されている，地上雨量観測所による面積雨量に関す
る既往研究例として，宝満川と小石原川流域における面 積雨量と最適観測密度に関する検討2)，標本論的方法を 適用した流域面積, 観測点数と面積雨量の誤差の関係を 明らかにした研究3), 都市中小河川流域における観測密 度が面積雨量の精度に与える影響を明らかにした研究4), 様々な降水イベントの時間分解能別の面積雨量の統計的 検討5)などが挙げられる.

レーダによる面積雨量に関する既往研究例は，千歳川 流域におけるレーダ雨量計データを用いた流域平均雨量 推定法のティーセン法による精度検証), 様々な降雨パ ターン別における地上観測の面積雨量とレーダ雨量計の 観測データを比較した研究7), 天塩川流域の局地豪雨を 対象とした流域平均雨量とレーダ雨量計と比較した研究 8)，地上観測とCバンドレーダの雨量データを用いた平 均面積雨量を推定する面積限界法の性能を検証した研究 9), 都市河川において地上観測所の流域平均雨量とX-MP の雨量データを比較検証した研究10)などが挙げられる.

このように，これまでの研究では，地上雨量観測所に よる各手法を用いた面積雨量の精度検証や流域内におけ 


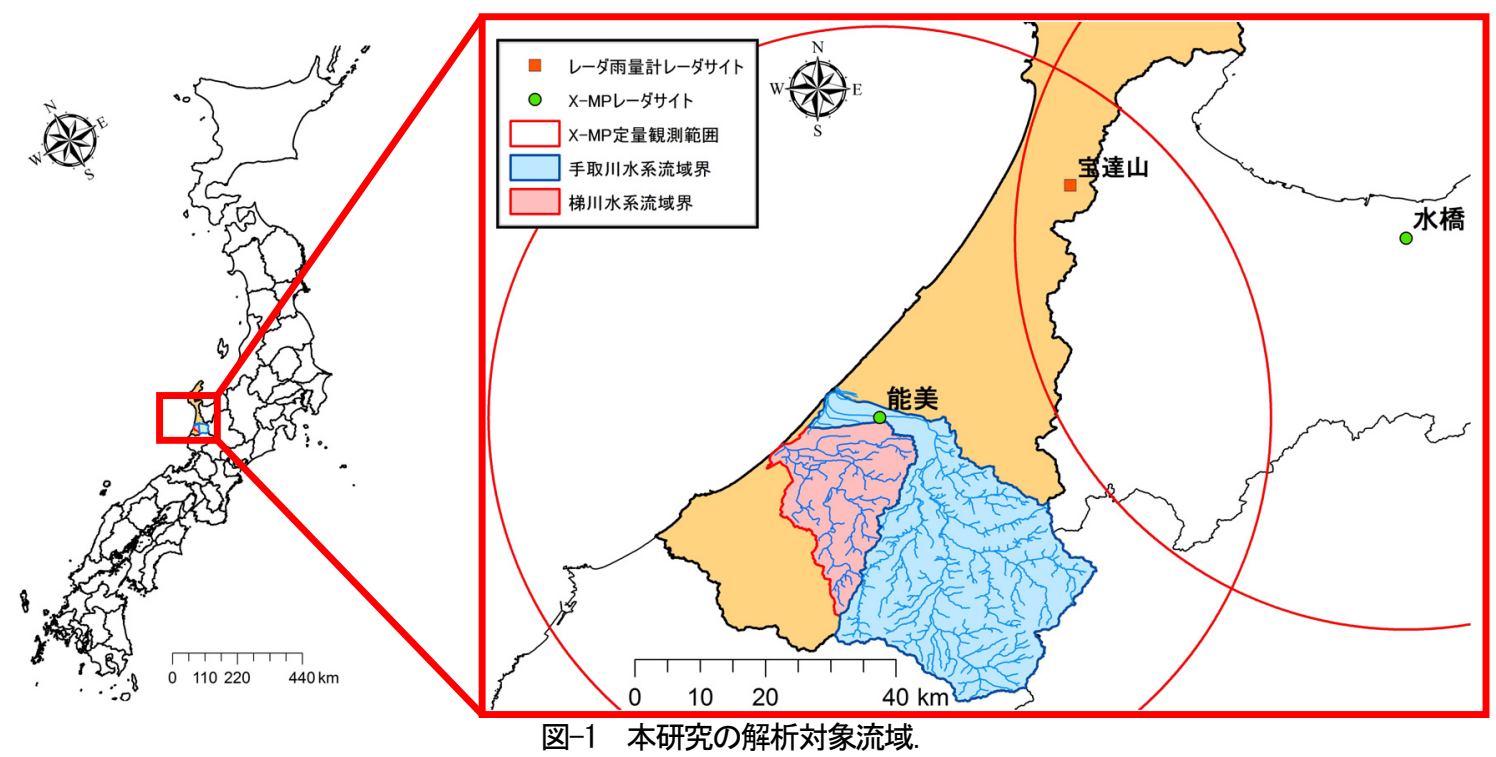

る観測所の最適設置数の検討をはじめ，レーダによる面 積雨量と地上観測所の面積雨量と対比させた検討がほと んどである。しかし，地上雨量観測所の観測所数を変化 させて地上雨量とレーダ雨量の面積雨量を時間分解能別 で対比させるとともに様々な条件下で検討した研究は少 なく，本運用が開始されたばかりのX-MPによる面積雨 量の同様な研究はほとんどない.

以上を鑑み，本研究では北陸地方のX-MPにおける定 量観測範囲内に位置する手取川と梯川を解析流域として, 地上雨量観測所による雨量データと，レーダ雨量計及び X-MPの雨量データを用いて面積雨量の比較検討を行う。 その際，両流域で間引き法を適用し，流域内の地上雨量 観測所の設置数を変化させて，地上雨量データによる面 積雨量と各レーダの雨量データによる面積雨量を時間分 解能別で比較する. 特に, X-MPの高解像・高頻度な雨 量データによる面積雨量への影響にも着目する。 また, 地上雨量観測所1箇所あたりの支配面積と面積雨量の誤 差推定について, レーダ雨量計とX-MPも含めて検討す ることで，観測方法の違いが地上雨量観測所の支配面積 に与える影響を明らかにする。ささらに，局地性降雨の一 つである地形性降雨に着目し，サブ流域の平均標高值を 用いて，地点観測である地上雨量の面積雨量と面的観測 であるX-MPの面積雨量との相違について検討する.

\section{2. 解析データについて}

\section{(1) 解析対象となる流域}

図-1は，本研究の対象流域として，石川県の中央部を 流れる手取川流域(青色の流域界) と西側に隣接する梯川 流域(赤色の流域界)の2つの中小河川流域とした. 手取 川流域は，幹線流路延長 $72 \mathrm{~km}$ ，流域面積 $809 \mathrm{~km}^{2}$ の一級 河川であり，流域内の平均標高は約 $849 \mathrm{~m}$ である。梯川 流域は, 幹線流路延長 $42 \mathrm{~km}$, 流域面積 $271 \mathrm{~km}^{2}$ の一級河
川であり，流域内の平均標高は約 $134 m$ である.

\section{（2）解析に使用したデータと降水イベント}

解析に用いた地上雨量観測所は，気象庁と国土交通省 水管理・国土保全局が管理する観測所とし，データ欠測 が少なく連続観測が行われている観測所として，手取川 流域で12箇所，梯川流域で6箇所とした. サブ流域の作 罒には，多くの流域で実績のあるティーセン法を用い， 流域内を満遍なく配置されるような観測所を抽出して作 成した。 なお，面積雨量は，以下の(1)式から算出した.

$$
R_{T}=\frac{\sum_{i=1}^{N} T_{i} r_{i}}{\sum_{i=1}^{N} T_{i}}, \quad T_{i}=\frac{a_{i}}{A}
$$

ここで， $R_{T}$ は面積雨量 $(\mathrm{mm} / \mathrm{h}), T_{i}$ はサブ流域 $i$ の ティーセン比， $r_{i}$ はサブ流域 $i$ の雨量 $(\mathrm{mm} / \mathrm{h}), N$ は対象 流域の分割数, $a_{i}$ はサブ流域 $i$ の支配面積 $\left(\mathrm{km}^{2}\right), A$ は流 域面積 $\left(\mathrm{km}^{2}\right)$ を示す.

レーダ雨量計については，国土交通省が全国に26基設 置・観測しているCバンドレーダであり，その降水量推 定值に，地上雨量観測所の観測データの補正を加えた合 成処理データを用いた。降水量は，以下の (2)式に示す Z-R関係式から算出されており，空間解像度は $1 \mathrm{~km}$ ，時 間分解能は5分である.

$$
Z_{h}=B R^{\beta}
$$

ここで， $R$ は降水強度 $(\mathrm{mm} / \mathrm{h}) ， Z_{h}$ は反射因子 $\left(\mathrm{mm}^{6} / \mathrm{mm}^{3}\right), B, \beta$ はZ-R関係式の雨滴定数を示す.

XバンドMPデータについては，北陸地方に設置され ている水橋・能美の2基のレーダで観測された合成処理 データを用いた. 降水量推定については, 以下の(3)式 に示すZ-R及び $\mathrm{K}_{\mathrm{DP}-\mathrm{R}}$ 関係式を，比偏波間位相差 $K_{D P}=0.1(\mathrm{deg} / \mathrm{km})$ を閾值として使い分けられており ${ }^{11)}$, 空 

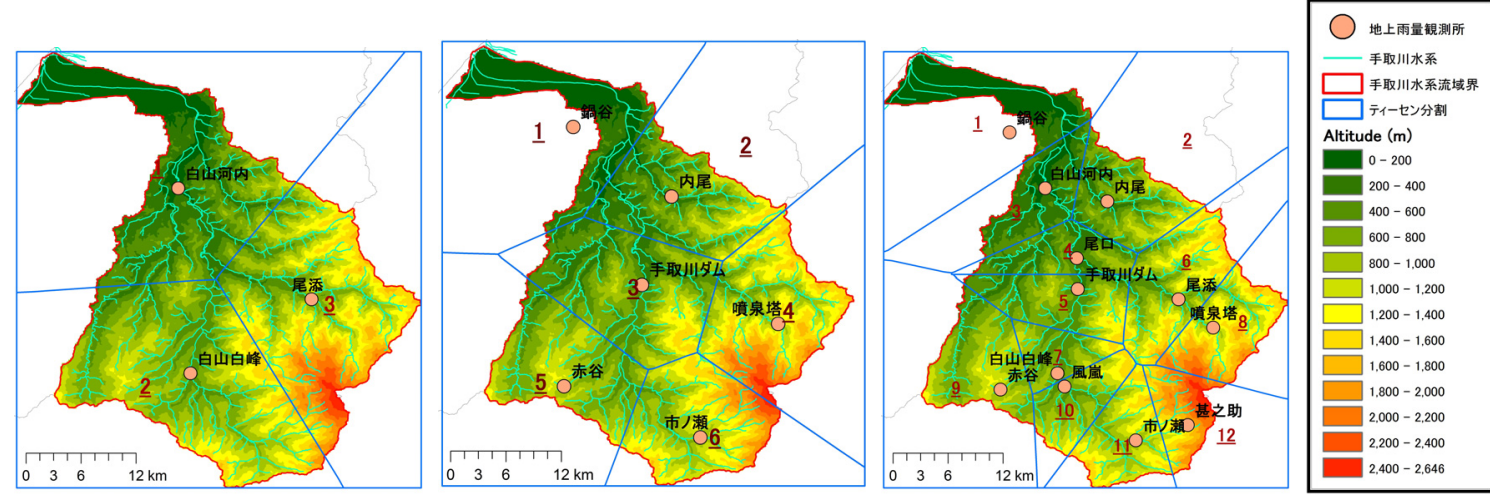

図-2 手取川流域におけるティーセン法を用いた流域分割図(左より3，6，12分割).
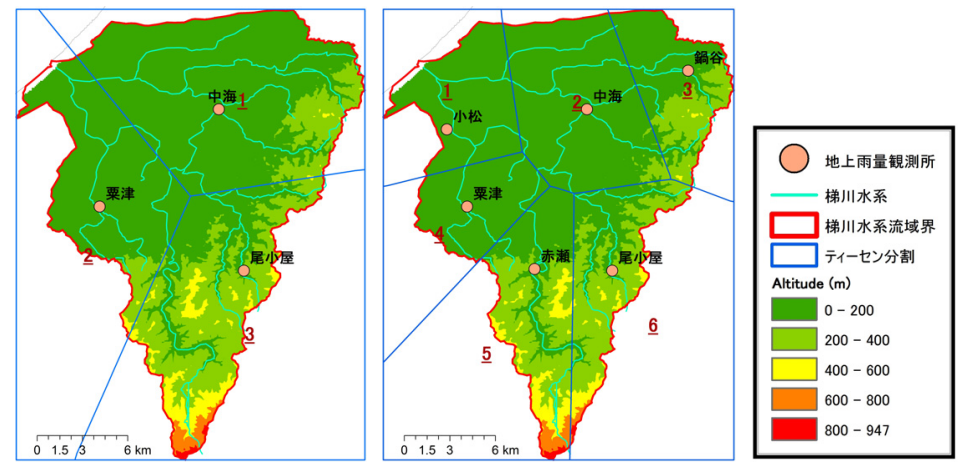

図-3 梯川流域におけるティーセン法を用いた流域分割図(左より3，6分割)．

間解像度は250m，時間分解能は1分である.

$$
\begin{aligned}
& Z_{h}=B R^{\beta} \quad\left(K_{D P} \leq 0.1\right) \\
& R=1.2 \times a_{1} \times K_{D P}^{0.815}
\end{aligned}
$$

$$
\left(K_{D P} \geq 0.1 \text { かつ } Z_{h} \geq 30\right)
$$

ここで， $R$ は降水強度 $(\mathrm{mm} / \mathrm{h}) ， Z_{h}$ は反射因子 $\left(\mathrm{mm}^{6} / \mathrm{mm}^{3}\right) ， K_{D P}$ は比偏波間位相差 $(\mathrm{deg} / \mathrm{km}), a_{1}$ は観測 仰角による定数 ${ }^{11)} ， B, \beta$ はZ-R関係式の雨滴定数を示す また，両流域とも能美レーダの定量観測範囲(半径 $60 \mathrm{~km}$ 圈内)に含まれている.さらに，X-MPにおいて強雨域の 後背地に生じる電波消散域に起因したデータ久測につい ては，データ補完を行わず，観測できているデータのみ を使用した。そのため，X-MPの面積雨量は，降水イベ ントによって過小になっている場合がある.

解析に使用した降水イベントは, 強い降水強度を伴う 降雨が生じたイベントを中心に，2011年では7月4日，8 月 18，25日，9月20，21，22日とし，2012年では7月 1，6， 7，13，21日，8月13，14日，9月11日，10月11，23日の 計16イベントの降水現象を解析対象とした.

\section{（3）解析方法}

本論では，主に3つの観点から地上雨量データによる 面積雨量とレーダ雨量計及びX-MPの雨量データによる 面積雨量の比較検討を行う。

1つ目は，解析流域において間引き法を適用し，地上
雨量観測所数を変化させた場合の面積雨量と各レーダに よる面積雨量を時間降水量と日降水量の2つの時間分解 能で比較する。手取川流域では，図-2のように流域内の 地上雨量観測所を3，6，12箇所の3パターン，梯川流域 では，図-3のように3，6箇所の2パターンで検討を行う. 2つ目は，上記の間引き法の解析結果から得られた各 パターンによるサブ流域面積と面積雨量を用いて，地上 雨量観測所1箇所女たりの支配面積と面積雨量による相 対推定誤差の関係を明らかにする. その際, 各レーダに よる面積雨量は，地上雨量データの面積雨量と解析条件 を一致させるため, 各パターンで作成されたサブ流域に あわせて雨量データを抽出して解析する. なお, 相対推 定䛊差は既往研究のに従って, 以下の(4)式より算出した.

$$
\begin{aligned}
& \sigma^{2}=\int_{A}(p-P)^{2} d A / A \\
& \frac{\Delta P}{P}=0.819 \frac{\sigma}{P} n^{-0.636}
\end{aligned}
$$

ここで，。は降雨の面積的な標準偏差，Aは流域面積 で $A=\int_{A} d A, P$ は面積雨量で $P=\int_{A} P d A / A, p$ は地 点雨量, $n$ は雨量観測所数を示す.

3つ目は，地形性降雨における地上雨量データとX-MP の面積雨量の比較を行う。そこで, 地形性降雨の現象発 生に最も影響を与える地形の標高值に着目し，各サブ流 域の平均標高值を用いて検証する. サブ流域の平均標高 值の算出にあたり, 標高データは, 国土地理院が発行し 


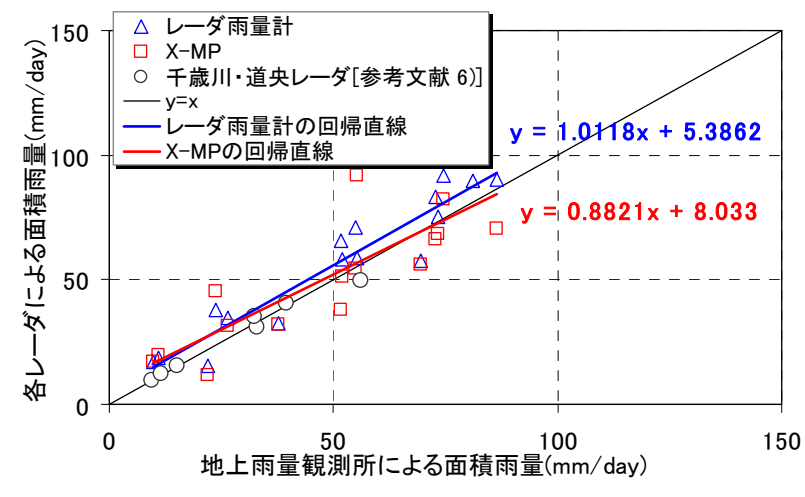

図-4 地上雨量と各レ一ダによる面積雨量の比較

（日降水量，梯川流域を3分割した場合）。

表-1 時間降水量の階級別における相関係数.

\begin{tabular}{c|c:c|c|c} 
梯川 & 地上 vs. レーダ雨量計 & & 地上 vs. X-MP \\
\hline \multirow{2}{*}{$\sim 1 \mathrm{~mm} / \mathrm{h}$} & 3 & 0.461 & 3 & 0.431 \\
& 6 & 0.614 & 6 & 0.590 \\
\hline \multirow{2}{*}{$1 \sim 5 \mathrm{~mm} / \mathrm{h}$} & 3 & 0.419 & 3 & 0.470 \\
& 6 & 0.456 & 6 & 0.581 \\
\hline \multirow{2}{*}{$5 \sim 10 \mathrm{~mm} / \mathrm{h}$} & 3 & 0.571 & 3 & 0.412 \\
& 6 & 0.478 & 6 & 0.436 \\
\hline \multirow{2}{*}{$10 \mathrm{~mm} / \mathrm{h} \sim$} & 3 & 0.703 & 3 & 0.740 \\
& 6 & 0.810 & 6 & 0.890 \\
\hline \hline \multirow{2}{*}{ 全体 } & 3 & 0.925 & 3 & 0.934 \\
& 6 & 0.946 & 6 & 0.959
\end{tabular}

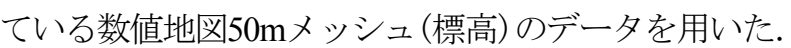
それにより，各サブ流域内に含まれる全ての標高データ を抽出して算術平均した值を平均標高值と定義した。対 象流域は，X-MPが高精度で雨量推定が可能なレーダサ イトから $30 \mathrm{~km}$ 圈内 ${ }^{12}$ にほぼ全域が含まれる梯川流域を対 象とし，流域内に地上雨量観測所を3箇所と6箇所配置し た場合で解析を行う。それにより，地上雨量データによ る面積雨量と, 高解像度で雨量推定ができるX-MPの面 積雨量との推定誤差 $(N E)$ を算出して比較検討を行う. なお，NEは以下の (5) 式から算出した.

$$
N E(\%)=\frac{\sum_{i=1}^{N}\left|R_{i}(r)-R_{i}(g)\right|}{\sum_{i=1}^{N} R_{i}(g)} \times 100
$$

ここで, $R_{i}(g)$ は地上雨量による面積雨量 $(\mathrm{mm} / \mathrm{h})$,

$R_{i}(r)$ はX-MPによる面積雨量 $(\mathrm{mm} / \mathrm{h}), N$ はデータ母数を 示す.

\section{3. 解析結果}

\section{（1）梯川流域における面積雨量の比較検討}

図-4に，流域を3分割した場合の日降水量における地 上雨量と各レーダによる面積雨量の関係を示す。また, 図中には同様な解析を行った既往研究のデータ6も示す. これより, レーダ雨量計は, 地上雨量データの面積雨量

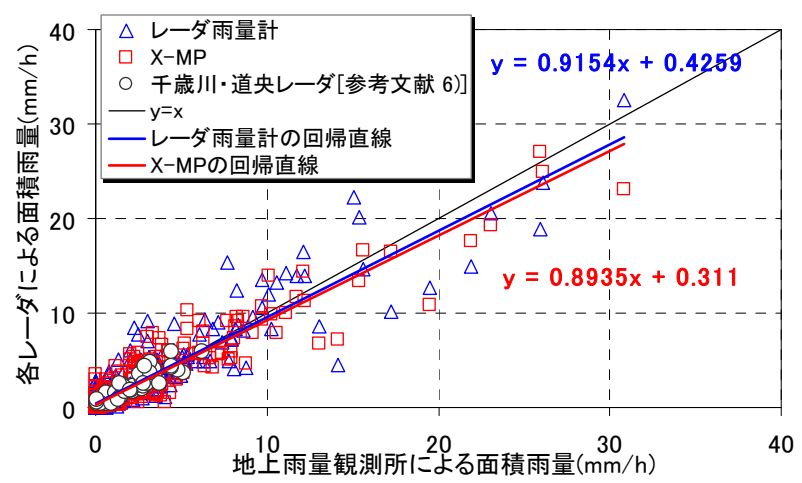

図-5＼cjkstart地上雨量と各レーダによる面積雨量の比較 (時間降水量，梯川流域を3分割した場合).

と比べて多少ではあるが過大傾向であることがわかる. X-MPの方は，電波消散域によるデータ欠測の影響もあ り, レーダ雨量計と比べると過大と過小の間で多少ばら ついたデータ分布になっているが，地上雨量とほぼ同等 のデータ特性であることがわかる。また，約 50 (mm/day)を境に, それ以下では両レーダの面積雨量 ともほぼ同じ值であるが，それ以上になると各レーダに よって異なる值になっていることがわかった。これは流 域を6分割した場合でも，同様な結果であった。この原 因の一つとして, 各レーダによる降水量推定方法の違い が考えられる. よって，日降水量を用いた各レーダの面 積雨量は，地上雨量の面積雨量とほぼ同等であり，流域 の分割数の影響も大きく受けないことがわかった.

図-5に，流域を3分割した場合の時間降水量における 地上雨量と各レーダによる面積雨量の関係を示し，表-1 に流域の分割数別における, 各種面積雨量の相関係数を まとめた：これにより既往研究通りの，流域を3分割より 6分割した方が，ほとんどの階級において相関係数が改 善することが確認できた，全体で見ると，レーダ雨量計 とX-MPとも地上雨量データとの高い相関性があり, XMPの方が多くの階級でわずかながら相関係数が高い.

階級別では，比較的降雨強度が弱い $10(\mathrm{~mm} / \mathrm{h})$ 末満ま では，X-MPよりレーダ雨量計の方が相関係数が高く， これは既往研究12)においても弱雨ではX-MPよりレーダ 雨量計の方が降水量推定精度が高いことが影響している と考えられる. そして，10 ( $\mathrm{mm} / \mathrm{h})$ 以上では，X-MPの方 がレーダ雨量計より多くの階級でわずかながら相関係数 が高く，これも既往研究12)の結果通り，特に強い降水強 度において高精度で降水量を推定できるX-MPの降水量 データの影響が大きいことが考えられる.

\section{（2）手取川流域における面積雨量の比較検討}

図-6に流域を3分割した場合の日降水量における地上 雨量と各レーダによる面積雨量の関係を示す，手取川流 域では，先述の梯川流域とは異なり，約 $30(\mathrm{~mm} / \mathrm{day}) の$ 境として，各レーダで異なるデータ特性が見られた。 そ れ以外は，梯川流域の解析結果と類似する結果であった. 


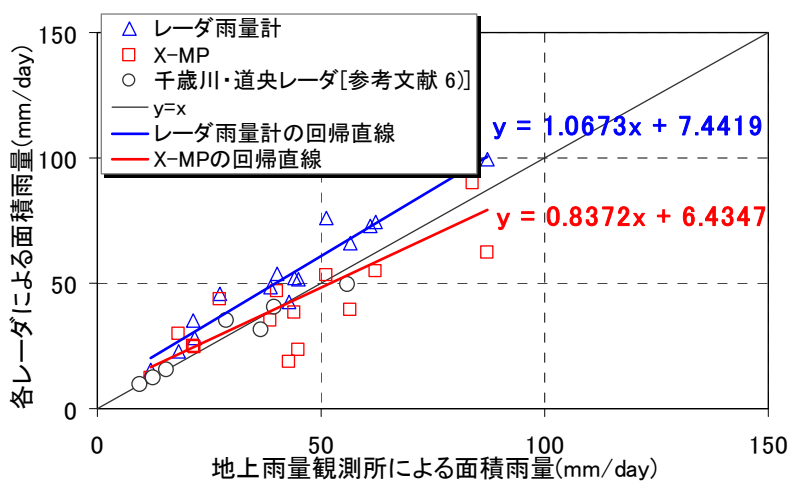

図-6＼cjkstart地上雨量と各レーダによる面積雨量の比較 (日降水量，手取川流域を3分割した場合).

表-2 時間降水量の階級別における相関係数.

\begin{tabular}{|c|c|c|c|c|}
\hline 手取川 & \multicolumn{2}{|c|}{ 地上 vs. レーダ雨量計 } & \multicolumn{2}{|c|}{ 地上 vs. X-MP } \\
\hline \multirow{3}{*}{$\sim 1 \mathrm{~mm} / \mathrm{h}$} & 3 & 0.502 & 3 & 0.405 \\
\hline & 6 & 0.547 & 6 & 0.478 \\
\hline & 12 & 0.619 & 12 & 0.507 \\
\hline \multirow{3}{*}{$1 \sim 5 \mathrm{~mm} / \mathrm{h}$} & 3 & 0.600 & 3 & 0.519 \\
\hline & 6 & 0.793 & 6 & 0.638 \\
\hline & 12 & 0.778 & 12 & 0.604 \\
\hline \multirow{3}{*}{$5 \sim 10 \mathrm{~mm} / \mathrm{h}$} & 3 & 0.405 & 3 & 0.400 \\
\hline & 6 & 0.549 & 6 & 0.601 \\
\hline & 12 & 0.679 & 12 & 0.641 \\
\hline \multirow{3}{*}{$10 \mathrm{~mm} / \mathrm{h} \sim$} & 3 & 0.710 & 3 & 0.836 \\
\hline & 6 & 0.905 & 6 & 0.958 \\
\hline & 12 & 0.859 & 12 & 0.923 \\
\hline \multirow{3}{*}{ 全体 } & 3 & 0.918 & 3 & 0.889 \\
\hline & 6 & 0.946 & 6 & 0.916 \\
\hline & 12 & 0.952 & 12 & 0.922 \\
\hline
\end{tabular}

図-7に，流域を3分割した場合の時間降水量における 地上雨量と各レーダによる面積雨量の関係を示し, 表-2 に流域の分割数別における, 各データの面積雨量の相関 係数をまとめた．これにより，先述通り3分割より6分割, さらに12分割した方が，多くの階級で相関係数が改善す ることが確認できた．ただし，本研究で作成したサブ流 域は，地上雨量観測所の選択によって同分割数でも異な る形状となり，本結果と同様になるとは必ずしも言えな いため，さらに検証していく必要がある．また，流域を 3分割した場合と12分割した場合の相関係数を比較して も，極端な相関係数の低下は見られないため，手取川の 流域規模であれば，流域を3分割した場合でも各レーダ の面積雨量と高い相関性が確保できることが言える.

全体で見ると, 先述通りレーダ雨量計とX-MPでは高 い相関性を維持しており, 梯川流域の場合とは異なり, 多くの階級でX-MPよりレーダ雨量計の方が相関係数が 高いことがわかる。これは，手取川の流域規模になると， X-MPのレーダサイトからの距離と降水量推定精度の関 係 ${ }^{12)}$ の影響が無視できなくなることが考えられる.

階級別では，梯川流域と同様な結果が得られ，降雨強 度が弱い階級ではレーダ雨量計が優位であり, 降雨強度 が強いほどX-MPの方が優位であることがわかった。 よって, 各レーダの雨量データは, レーダの観測仕様や 推定方法により優位な降水強度の領域があるため, 本解

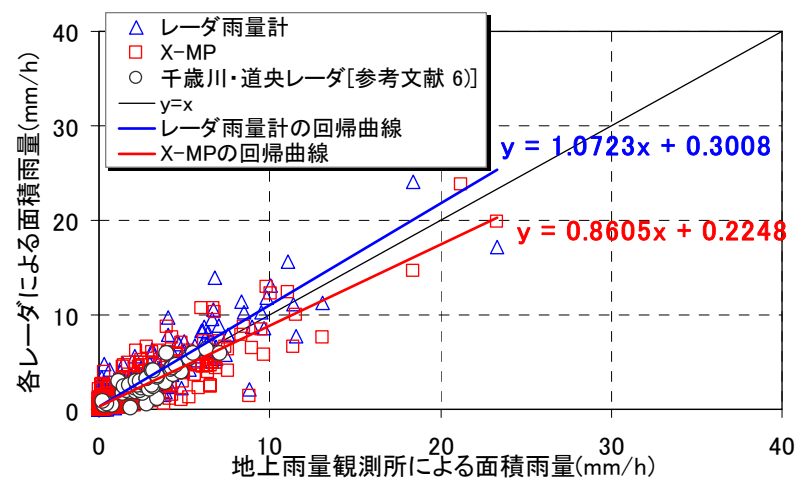

図-7＼cjkstart地上雨量と各レーダによる面積雨量の比較 (時間降水量，手取川流域を3分割した場合)。

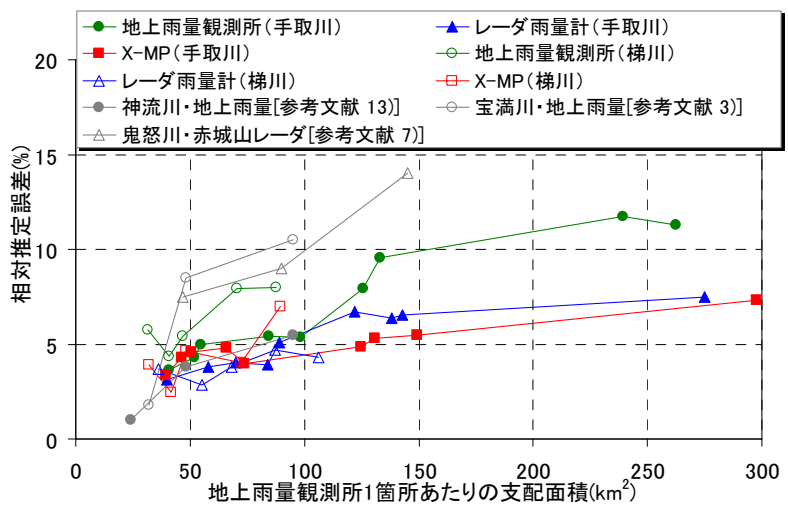

図-8 地上雨量観測所1箇所あたりの支配面積と面積雨量の 相対推定誤差の関係.

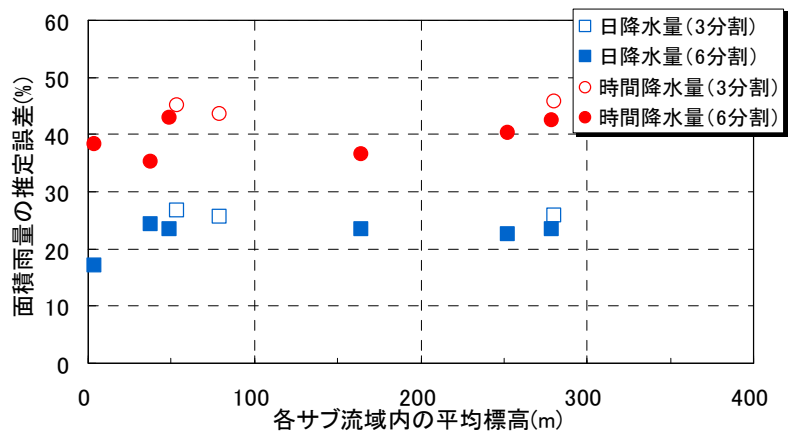

図-9 梯川流域における各サブ流域の平均標高値と地上雨量 とX-MPIよる面積雨量の推定誤差.

析結果より降雨強度に応じて各レーダデータを使い分け ることが，非常に有効であることが明らかになった。

\section{（3）地上雨量観測所1箇所あたりの支配面積と相対推定 誤差の関係に関する検討}

図-8に，両流域の各種面積雨量における地上雨量観測 所1箇所あたりの支配面積と相対推定誤差の関係を示す. また，図中には既往研究3), 7), 13)における, 各流域の同様 な解析結果も追加している。 それにより, 両流域とも, 既往研究の解析結果より多少相対推定誤差が小さくなる 結果となったが，データ特性が大きく異なることはな かった. 地上雨量データによる面積雨量は，支配面積が 増加すると相対推定誤差も増加する傾向であるが，各 
レーダによる面積雨量では，支配面積の増加に対して緩 やかに増加する傾向であることがわかった．この原因の 一つとして，面的な雨量推定が可能であるレーダの観測 方法の違いが最も大きな要因であることが考えられる.

\section{（4）地形性降雨における面積雨量の検討結果}

図-9には，各サブ流域の平均標高值と地上雨量とXMPの面積雨量から算出したNEの関係を示す．本解析で は，2章(3)項で先述した通り，X-MPが高精度で観測可 能な範囲である梯川流域を対象とした。 これにより，今 回の解析では, 時間及び日降水量ともサブ流域の平均標 高值と推定誤差に有意性は見られなかった. よって, サ

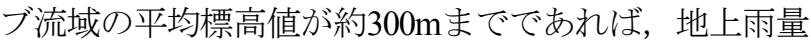
とX-MPの面積雨量に相違性は見られないことわかった。 今後は, より高い平均標高値を含むサブ流域で検討す る必要がある，また，雨域の規模やその通過する経路な じを把握した上で降水イベントを選択し，地上雨量観測 所の位置関係も十分考慮しながら検証する必要がある.

\section{4. 結論}

X-MPの定量観測範囲内を流孔る手取川流域と梯川流 域を解析対象として, 地上雨量データと高解像度のレー ダデータを用いて, 既往研究結果と比較しながら, 様々 な条件下で面積雨量の比較検討を行った。 ここで，本研 究によって得られた知見をまとめる.

\section{（1）手取川流域及び梯川流域における各種面積雨量の 解析結果}

両流域とも既往研究の通りの，流域の分割数が増や寸 ことで，地上雨量による面積雨量は各レーダによる面積 雨量に近づくことを確認できた．また，手取川の流域規 模であれば，流域の分割数が3つでも，相関係数から地 上雨量による面積雨量と各レーダによる面積雨量は，ほ ぼ同等であった，時間降水量別の比較では，降雨強度の 弱い領域ではレーダ雨量計, 強い領域ではX-MPの方が 相関係数が高くなることが明らかになった.

\section{（2）地上雨量観測所1箇所あたりの支配面積と相対推定 誤差の関係に関する解析結果}

地上雨量による面積雨量は既往研究の通り 33 , 7), 13), 支 配面積が増加すると相対推定誤差も増加するが，レーダ 雨量計やX-MPによる面積雨量では，緩やかに増加する 傾向であった. その要因の一つとして，レーダでは面的 な雨量観測が可能であるという観測方法の違いが最も大 きく影響していることが考えられる.

\section{（3）地形性降雨における面積雨量の解析結果}

サブ流域の平均標高值に着目して, 地上雨量とX-MP
の面積雨量と比較した結果，サブ流域の平均標高值が約 300mまでであれば，地上雨量とX-MPによる面積雨量に は相違性は見られないことがわかった。

謝辞：本研究は，国土交通省「XバンドMPレーダに関 する技術開発コンソーシアム」を通じてデータの提供を 受けた。 また，レーダ雨量計及びX-MPの観測仕様に関 して，国土交通省国土総合政策技術研究所の土屋修一博 土より助言をいただいた。ここに記して謝意を表す。

\section{参考文献}

1) 川畑幸夫 : 水文気象学, 地人書館, 268pp., 1960.

2) 中川吉雄 : 雨量観測点の密度と面積雨量, 天気, Vol.3, No.2, pp.14-16, 1955.

3) 橋本健, 佐藤一郎 : 面積雨量の精度と雨量観測所数, 土木 技術資料，Vol.16，No.12，pp.35-41，1974.

4) 福岡捷二, 谷岡康, 高本正彦: 都市中小河川流域における 雨量観測所の密度が面積雨量精度に与える影響, 水工学論 文集，Vol.37，pp.27-32，1993.

5) U.S. Weather Bureau: The Reliability of Areal Rainfall Determination, Hydrometeorological Report, No.5, pp.234-259, 1974.

6) 山田正, 日比野忠史, 中津川誠, 藤沢充哲, 森永博史 : レーダ雨量計情報の動画像解析による降雨予測手法の提案 と流域平均雨量の推定法に関する研究, 土木学会論文集, Vol.558/II-38, pp.13-30, 1997.

7) 吉野文雄, 水野雅光, 井川貴史：レーダ雨量計から見た降 雨の時空間特性について, 水理講演会論文集, Vol.32, pp.1-6, 1988.

8) 田中雅基, 高柳和己，田中康寛 : 天塩川流域の局地豪雨に おける流域平均雨量の特性評価，国土交通省北海道開発局 第54回 (平成22年度) 北海道開発技術研究発表会, AA21, 2011.

9) Krajewski, W, F., Rexroth, D, T., Morrissey, M, L: The Accuracy of the Area-Threshold Method: A Model-based Simulation Study, Journal of Applied Meteorology, Vol.31, pp.1396-1406, 1992.

10）原田守博, 羽澄貴史 : XバンドMPレーダ情報に基づく局地 的短時間豪雨の雨域性状の確率論的評価, 土木学会論文集 B1 (水工学), Vol.70, No.4, pp.I_511-I_516, 2014.

11) Maesaka, T., Maki, M., Iwanami, K., Tsuchiya, S., Kieda, K. and Hoshi A.: Operational Rainfall Estimation by X-band MP Radar Network in MLIT, Japan, Proceedings of 35th Conference on Radar Meteorology, September 26-30, Pittsburgh, USA, 142, 2011.

12）林義晃, 手計太一, 永島健, 山崎惟義 : 北陸地方における XバンドMPレーダの降水量推定精度に関する時空間分布特 性，水文・水資源学会誌，Vol.28，No.5，pp.165-175，2015。 13）竹内俊雄, 江川太郎, 神谷隆太郎 : 山地流域における一雨 雨量の降雨分布について, 土木研究所報告, No.106, pp.4561, 1961.

(2015. 9. 30受付) 